\section{Predicting Need for Phosphorus Fertilizer by Soil Testing During Seeding of Cool Season Grasses}

\author{
Stephanie C. Hamel and Joseph R. Heckman ${ }^{1}$ \\ Plant Biology and Pathology Department, Rutgers, The State University of \\ New Jersey 59 Dudley Road, New Brunswick, NJ 08901
}

Additional index words. turf establishment, pasture establishment, Kentucky bluegrass, tall fescue, perennial ryegrass, soil test calibration, soil test critical level, aluminum

\begin{abstract}
Recent changes in soil testing methodology, the important role of $P$ fertilization in early establishment and soil coverage, and new restrictions on $P$ applications to turf suggest a need for soil test calibration research on Kentucky bluegrass (Poa pratensis L.), tall fescue (Festuca arundinacea Schreb), and perennial ryegrass (Lolium perenne L.). Greenhouse and field studies were conducted for $\mathbf{4 2}$ days to examine the relationship between soil test $P$ levels and $P$ needs for rapid grass establishment using $23 \mathrm{NJ}$ soils with a Mehlich-3 extractable P ranging from 6 to $1238 \mathrm{mg} \cdot \mathrm{kg}^{-1}$. Soil tests (Mehlich-1, Mehlich3 , and Bray-1) for extractable $P$ were performed by inductively coupled plasma-atomic emission spectroscopy (ICP). Mehlich-3 extractable $P$ and Al were measured to evaluate the ratio of $P$ to $A l$ as a predictor of need for $P$ fertilizer. Kentucky bluegrass establishment was more sensitive to low soil $P$ availability than tall fescue or perennial ryegrass. Soil test extractants Mehlich-1, Bray-1, or Mehlich-3 were each effective predictors of need for $\mathrm{P}$ fertilization. The ratio of $\mathrm{P}$ to $\mathrm{Al}$ (Mehlich-3 P/Al \%) was a better predictor of tall fescue and perennial ryegrass establishment response to $P$ fertilization than soil test $P$ alone. The Mehlich-1, Bray-1, and Mehlich-3 soil test $P$ critical levels for clipping yield response were in the range of 170 to $280 \mathrm{mg} \cdot \mathrm{kg}^{-1}$, depending on the soil test extractant, for tall fescue and perennial ryegrass. The Mehlich-3 P/Al (\%) critical level was $42 \%$ for tall fescue and $33 \%$ for perennial ryegrass. Soil test critical levels, based on estimates from clipping yield data, could not be determined for Kentucky bluegrass using the soils in this study. Soil testing for $P$ has the potential to aid in protection of water quality by helping to identify sites where $P$ fertilization can accelerate grass establishment and thereby prevent soil erosion, and by identifying sites that do not need $P$ fertilization, thereby preventing further $P$ enrichment of soil and runoff. Because different grass species have varying critical $P$ levels for establishment, both soil test $P$ and the species should be incorporated into the decision-making process regarding $P$ fertilization.
\end{abstract}

Grass seedlings often respond positively to $P$ fertilization because seed $P$ reserves are easily exhausted because rapidly growing and dividing cells use P. Seedling root systems have limited contact with $\mathrm{P}$ in the soil, and diffusion, the dominant mechanism by which $\mathrm{P}$ is supplied to plant roots from the soil solution, is an especially slow process when the soil P concentration is low (Barber, 1995). Thus, $P$ fertilizer is often routinely applied at the time of seeding cool season grasses in an effort to hasten establishment.

Indiscriminate use of $\mathrm{P}$ fertilizers, without regard to soil test $\mathrm{P}$ level, has come under increased scrutiny. Excessive $P$ accumulation in soils and its associated problems with runoff and water quality deterioration are of increasing concern (Correll, 1998; Sharpley et al., 1994; Sims, 1998). In an attempt to limit $\mathrm{P}$ nutrient runoff, some municipalities are regulating $\mathrm{P}$ fertilizer application to turf

Received for publication 2 June 2006. Accepted for publication 15 July 2006.

${ }^{1}$ To whom reprint requests should be addressed; e-mail heckman@aesop.rutgers.edu.
(Rosen and Horgan, 2005; The Citizen of Morris County, 1992). However, rapid soil coverage by an increasingly dense sod is crucial to the prevention of surface nutrient runoff and erosion. Therefore, the use of $\mathrm{P}$ fertilizer may sometimes be justified, even on high $P$ soils, if it hastens grass establishment.

Based on soil samples received from the public in 2004 by the Rutgers Soil Testing Laboratory (analyzed using Mehlich-3 soil test), $24 \%$ of samples had soil test $P$ ratings in the below optimum range $\left(<36 \mathrm{mg} \cdot \mathrm{kg}^{-1}\right)$, $37 \%$ in the optimum range (36-69 $\left.\mathrm{mg} \cdot \mathrm{kg}^{-1}\right)$, and $39 \%$ in the above optimum range $(>69$ $\left.\mathrm{mg} \cdot \mathrm{kg}^{-1}\right)$. These soil test $\mathrm{P}$ ratings are for general crops and are not specific for grass establishment and the diversity of soils onto which grasses are seeded. To make sound recommendations, it is imperative to know where $\mathrm{P}$ fertilization is necessary and where it is inappropriate. Furthermore, the ability of $\mathrm{P}$ fertilizer rates to positively influence growth and establishment of cool season grasses, in relationship to a range of soil test $\mathrm{P}$ levels, needs to be determined.

There are three soil test methods widely used by university and private soil test laboratories that operate within the Mid-
Atlantic region of the United States. Soil test laboratories are increasingly adopting the Mehlich-3 soil test extractant based on correlations with previous soil test methods. To date, very limited field calibration research has been conducted on local soils. Analysis of the soil test extractions by ICP, in place of colorimetric analysis (Mallarino, 2003), is another recent development in soil testing. Thus, given the environmental concerns with $P$ fertilization and recent changes in soil test laboratory methodology, there is a need to conduct soil test calibration research with a full range of economically important agronomic and horticultural crops.

Previous research in Pennsylvania by Turner and Waddington (1983) on cool season grass establishment in relation to soil test $\mathrm{P}$ found that $\mathrm{P}$ applications generally increased turf density on low $\mathrm{P}$ soils. Initial Bray-1 soil $\mathrm{P}$ levels of $60 \mathrm{~kg} \cdot \mathrm{ha}^{-1}$ were not satisfactory for rapid cool season turfgrass establishment. Establishment improved when soil P levels were increased to 78 to $157 \mathrm{~kg} \cdot \mathrm{ha}^{-1}$, and no effect was seen with Bray-1 P levels above $157 \mathrm{~kg} \cdot \mathrm{ha}^{-1}$. The positive effect was noted most strongly at 3 to 4 weeks after germination possibly as a result of exhaustion of seed $P$ reservoirs. Although turf could be established $\mathrm{P}$ at $60 \mathrm{~kg} \cdot \mathrm{ha}^{-1}$ soil without additional $\mathrm{P}, \mathrm{P}$ fertilization resulted in quicker ground coverage. Bray-1 P levels of 110 to 180 $\mathrm{kg} \cdot \mathrm{ha}^{-1}$ soil were most satisfactory for promoting rapid establishment.

A recent study (Carrol et al., 2005) in Maryland examined tall fescue seedling growth in response to $\mathrm{P}$ fertilization and found that soils having $>97 \mathrm{mg} \cdot \mathrm{kg}^{-1}$ Mehlich-3 P (by ICP) did not exhibit responses to P fertilization; however, on soils having 52 to 66 $\mathrm{mg} \cdot \mathrm{kg}^{-1}$ Mehlich-3 $\mathrm{P}$, the $\mathrm{P}$ application of $96 \mathrm{~kg} \cdot \mathrm{ha}^{-1}$ was found to increase seedling growth by $34 \%$.

In turfgrass establishment, it is not uncommon to begin seedings on new sites where the native soils are strongly acidic and limestone applications are not given sufficient time to adjust soil $\mathrm{pH}$ before seeding. Aluminum toxicity is a growth-limiting factor in acid soils for many grasses (Liu et al., 1995). In acid soils, $\mathrm{P}$ binds with $\mathrm{Fe}, \mathrm{Al}$, and $\mathrm{Mn}$ (Barber, 1980), although in well-limed soils, $\mathrm{P}$ is more abundant in the soil solution, although precipitation with $\mathrm{Ca}, \mathrm{Mg}$, and $\mathrm{Al}$ is still common (Hull, 1997). Aluminum, which is bound in insoluble forms at higher $\mathrm{pH}$, may be released into soil solution as soil $\mathrm{pH}$ lowers with toxic effects on roots and, therefore, limiting plant growth (Hull, 1997). Because $\mathrm{Al}$ is known to react with $\mathrm{P}$ and render it unavailable (Iyamuremye and Dick, 1996), soils with high levels of Al are expected to compromise $\mathrm{P}$ availability to plants. Conversely, high $\mathrm{P}$ content has been shown to reduce Al toxicity in plants as a result of precipitation of $\mathrm{Al}$ (Kochian and Jones, 1997).

Phosphorus fertilizer recommendations based on soil testing typically rely on extractable $\mathrm{P}$ alone, but some soil test laboratories are beginning to use the ratio of extractable 
$\mathrm{P}$ to $\mathrm{Al}$ to adjust $\mathrm{P}$ fertilizer recommendations. The concept behind this approach is that extractable Al provides an indication of the P-fixing capacity of the soil (Jokela et al., 1998; Lee and Bartlett 1977; Magdoff et al., 1999). Research in Quebec Province (Khiari et al., 2000) examined the use of extractable Al to improve $\mathrm{P}$ recommendations for potato (Solanum tuberosum L.). They found that the ratio of $\mathrm{P}$ to $\mathrm{Al}$ extracted with Mehlich-3 extractant was a better predictor of both crop response and environmental risk than extractable $\mathrm{P}$ alone.

Our objective was to determine the ICP Mehlich-1, Mehlich-3, and Bray-1 soil test $\mathrm{P}$ critical levels needed for rapid establishment of Kentucky bluegrass, tall fescue, and perennial ryegrass. Additionally, the Mehlich3-extractable $\mathrm{P}$ to $\mathrm{Al}$ ratio was evaluated for its ability to predict a grass establishment response.

\section{Materials and Methods}

Two greenhouse and two field studies were conducted. For the greenhouse studies, soils were collected from the surface $20 \mathrm{~cm}$ at 23 different New Jersey sites. The soils are listed in Table 1 by site (soil) number, taxonomy, and chemical characteristics. The soils were air-dried and passed through a 7-mm sieve before initiation of the greenhouse experiments. Subsamples were analyzed for $\mathrm{pH}$ using a 1:1 soil volume to water ratio, organic matter content by the loss on ignition method (Storer, 1984), and extractable P using Mehlich-1, Mehlich-3 (Mehlich, 1984), and Bray-1 (Bray and Kutz, 1945). Also, extractable Al was determined using Mehlich-3 to examine the ratio of extractable $\mathrm{P}$ to $\mathrm{Al}$ expressed as a percentage (Magdoff et al., 1999). All soil test methods were performed following Recommended Soil Test Procedures for the Northeast (Sims and Wolf, 1995) and all extractions were analyzed by ICP (Thermo Jarell Ash Model Enviro-II ICAP) at the Univ. of Delaware Soil Test Laboratory. The shaking time for the Mehlich-3 soil test extraction was 5 min. as shown on the http://ag.udel.edu/ extension/agnr/soiltesting.htm version of Recommended Soil Test Procedures for the Northeast (Sims and Wolf, 1995).

Greenhouse Expt. 1 examined the relationship between extractable $\mathrm{P}$ and relative growth of three species of grass: Kentucky bluegrass var. 'Midnight', tall fescue var. 'Coronado', and perennial ryegrass var. 'Elite BFP'. Observations (unpublished data) from our preliminary investigations of grass species sensitivity to $\mathrm{P}$ availability suggested that the germplasm chosen for this study were representative of the species. Before seeding in 1-L pots containing $900 \mathrm{~g}$ of soil, each pot was fertilized with $\mathrm{N}$ at the rate of $38 \mathrm{mg} \cdot \mathrm{kg}^{-1}$ soil using $\mathrm{NH}_{4} \mathrm{NO}_{3}$ and with $\mathrm{K}$ at the rate of $50 \mathrm{mg} \cdot \mathrm{kg}^{-1}$ soil using $\mathrm{K}_{2} \mathrm{SO}_{4}$. Dolomitic or calcitic limestone was applied, as needed, to achieve a target soil $\mathrm{pH}$ of 6.5 based on each individual soil test report and as recommended by Rutgers Cooperative Research \& Extension for cool season grasses. The grasses were seeded on the same day as the fertilizer and liming materials were added to the soil. Nitrogen was reapplied every $14 \mathrm{~d}$ at the rate of $38 \mathrm{mg} \cdot \mathrm{kg}^{-1}$ soil using a solution of $\mathrm{NH}_{4} \mathrm{NO}_{3}$. Pots were watered, as necessary, to keep soil moist. The greenhouse temperature was maintained at 18 to $22^{\circ} \mathrm{C}$ for $13 \mathrm{~h}$ per $\mathrm{d}$ and then 16 to $20^{\circ} \mathrm{C}$ for $11 \mathrm{~h}$ at night. Plant height was measured weekly over a period of 6 weeks in the greenhouse. Relative growth was calculated as plant height or dry matter yield on soil without $\mathrm{P}$ fertilizer to plant height or dry matter yield on soil amended with $\mathrm{P}$ at $357 \mathrm{mg} \cdot \mathrm{kg}^{-1}$ soil as $\mathrm{Ca}\left(\mathrm{H}_{2} \mathrm{PO}_{4}\right)_{2} \cdot \mathrm{H}_{2} \mathrm{O}$. At the end of the 42-d period, the biomass that had accumulated in each pot was determined by clipping the grass at $2 \mathrm{~cm}$ above the soil surface. The clippings were oven-dried at $70{ }^{\circ} \mathrm{C}$ for $48 \mathrm{~h}$ and then weighed.

In greenhouse Expt. 2, using three of the soils (soils 16, 17, and 25 in Table 1), the responses of each grass species to six rates $(0$, $25,50,100,200$, and $400 \mathrm{mg} \cdot \mathrm{kg}^{-1}$ ) of $\mathrm{P}$ fertilizer were also examined. Fertilizer N, K, $\mathrm{S}$, and limestone were applied as previously described in greenhouse Expt. 1. Plant height and clipping yields were also measured as described previously.

Two field experiments were conducted using six rates of $P$ fertilizer $(0,25,50,100$, 200, and $400 \mathrm{mg} \cdot \mathrm{kg}^{-1}$ ). Field Expt. 1 was conducted on soil 25 near Adelphia, N.J., during the fall of 1999 and field Expt. 2 was conducted on soil 22 near Pittstown, N.J., during the spring of 2000. Each species of grass was seeded at the rate of $2056 \mathrm{seeds} / \mathrm{m}^{-2}$. In these field trials, grass response to $\mathrm{P}$ was evaluated by visual ratings of density, or soil coverage, on a scale of 0 to 9 with $9=$ best.

Treatments in the greenhouse experiments were replicated three times and were completely randomized. In the field experiments, the treatments were replicated six times and were conducted using a randomized complete block design. Analysis of variance and general linear models were performed using SAS GLM or SAS ANOVA (SAS Institute, 1997). A Cate-Nelson analysis (Cate and Nelson, 1965) was used to estimate the critical soil test P levels for each soil test extractant and for each grass species. The relationship between plant response (height or dry matter yield) and soil test $\mathrm{P}$ was examined by partitioning the data into responsive and nonresponsive sites. The procedure was modified by estimating the soil test critical level as the point where the line from the regression equation intersected a horizontal line of $90 \%$ relative response.

Table 1. Soil classification, soil test $\mathrm{P}$ with each of three extractants and Mehlich-3 extractable Al on 23 experimental soils from New Jersey. ${ }^{2}$

\begin{tabular}{|c|c|c|c|c|c|c|c|c|}
\hline \multirow{2}{*}{$\begin{array}{l}\text { Experimental } \\
\text { soil }\end{array}$} & \multirow{2}{*}{ Soil series and taxonomy } & \multirow{2}{*}{\multicolumn{2}{|c|}{ Organic }} & \multicolumn{3}{|c|}{ Soil test Extractable P (ICP) } & \multicolumn{2}{|c|}{ Soil test Extractable Al (ICP) } \\
\hline & & & & Bray & Mehlich-1 & Mehlich-3 & Mehlich-3 & Mehlich-3 \\
\hline 2 & Nassau; silt loam, mixed, mesic, Lithic Dystrochrept & 1.5 & 7 & 905 & 1174 & 1238 & 621 & 199 \\
\hline 3 & Annandale; gravelly loam, mixed, mesic Typic Fragiudult & 1.3 & 5.6 & 37 & 19 & 48 & 1046 & 5 \\
\hline 6 & Bucks; silt loam, mixed, mesic, Typic Hapludult & 1.5 & 7.2 & 259 & 203 & 409 & 1081 & 38 \\
\hline 7 & Quakertown; silt loam, mixed, mesic Typic Hapludult & 1.1 & 6.5 & 73 & 37 & 74 & 891 & 8 \\
\hline 10 & Sassafras; sandy loam, siliceous, mesic Typic Hapludult & 0.4 & 6.1 & 112 & 90 & 209 & 672 & 31 \\
\hline 11 & Sassafras; sandy loam, siliceous, mesic Typic Hapludult & 1.5 & 4.5 & 7 & 4 & 25 & 1009 & 3 \\
\hline 13 & Freehold; sandy loam, mixed, mesic Typic Hapludult & 0.9 & 6 & 152 & 90 & 196 & 954 & 21 \\
\hline 14 & Freehold; sandy loam, mixed mesic Typic Hapludult & 0.5 & 5.5 & 89 & 35 & 101 & 758 & 13 \\
\hline 15 & Freehold; sandy loam, mixed mesic Typic Hapludult & 0.4 & 5.7 & 124 & 59 & 142 & 859 & 17 \\
\hline 16 & Woodstown; loam, siliceous, mesic Aquic Hapludult & 1.4 & 4.1 & 13 & 4 & 6 & 2206 & 0.3 \\
\hline 17 & Adelphia; loam, mixed, mesic Aquic Hapludult & 2.2 & 4 & 34 & 10 & 40 & 1258 & 3 \\
\hline 24 & Holmdel; sandy loam, mixed, mesic Aquic Hapludult & 1.2 & 6.6 & 123 & 98 & 145 & 515 & 28 \\
\hline 25 & Freehold; loam, mixed, mesic Typic Hapludult & 0.9 & 6.5 & 49 & 28 & 51 & 431 & 12 \\
\hline 26 & Nixon; loam, mixed, mesic Typic Hapludult & 0.6 & 6.7 & 127 & 73 & 129 & 431 & 30 \\
\hline 27 & Sassafras; sandy loam, siliceous, mesic Typic Hapludult & 3.2 & 5.9 & 100 & 24 & 120 & 748 & 16 \\
\hline
\end{tabular}

${ }^{2}$ Soil test extractable P and extractable Al were measured with an ICP instrument. All soils were collected from the 0 - to 20 -cm surface layer. 
Table 2. Correlations for various P soil test extractants measured by an ICP instrument for the 23 soils on which Kentucky bluegrass (KB), tall fescue (TF), and perennial ryegrass (PR) were grown in the greenhouse and measured for plant height on days $21,28,35$, and 42 and clipping yield on day $42 .^{z}$

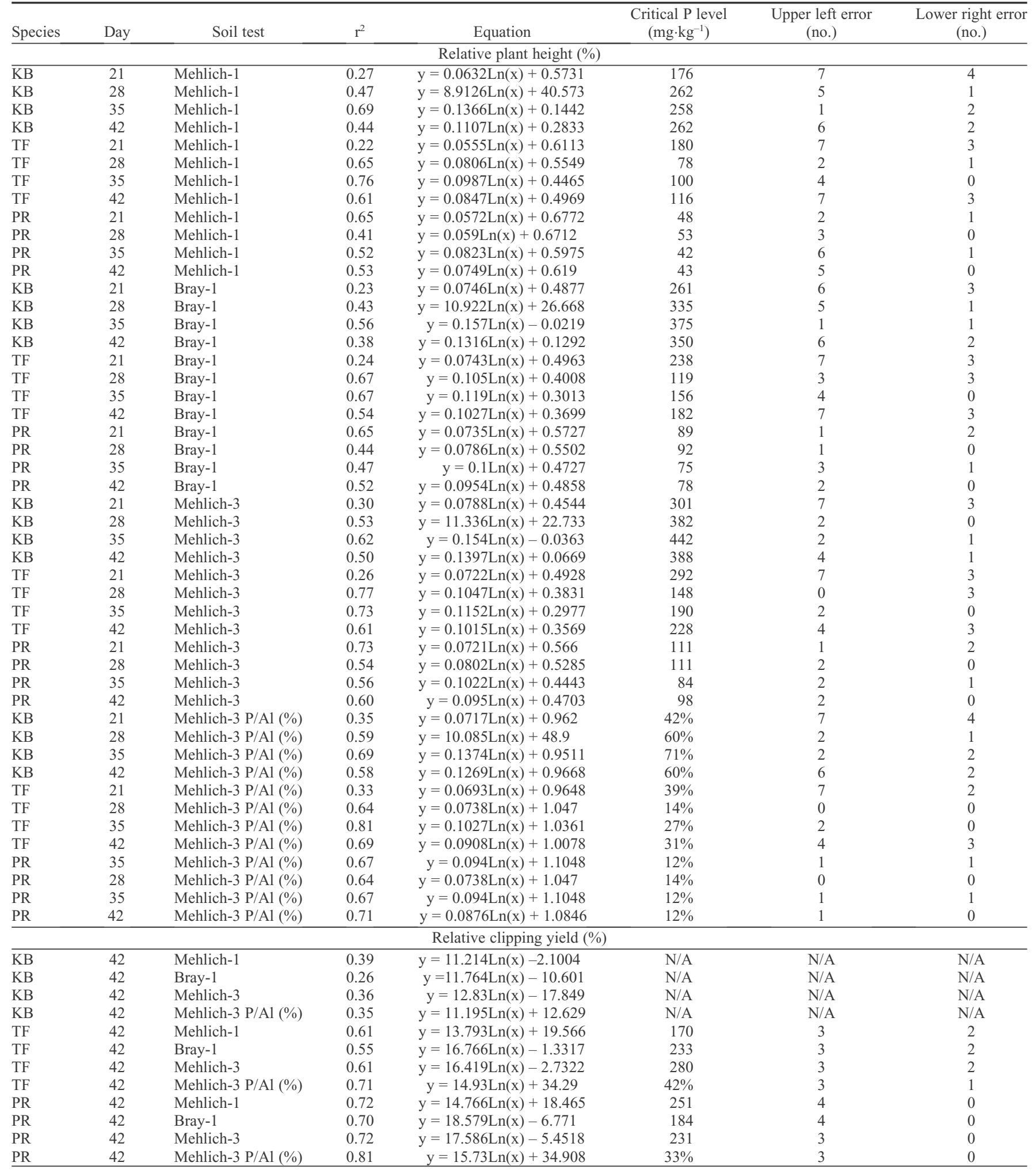

${ }^{\mathrm{z}}$ Critical levels of extractable $\mathrm{P}$ and Mehlich-3 P/Al (\%) were estimated as the point where the line from the regression equation intersected a horizontal line of $90 \%$ relative response. Incorrect predictions concerning P fertilization were counted as the number of error or data points in the upper left quadrant, representing incorrect predictions of unnecessary $\mathrm{P}$ fertilizaion, and in the lower right quadrant, representing incorrect predictions to not add $\mathrm{P}$ fertilizer when it is needed. N/A, not available. 


\section{Results and Discussion}

In greenhouse Expt. 1, the three grass species varied markedly in their ease of establishment from seed and in their growth response to $\mathrm{P}$ fertilization. Kentucky bluegrass was clearly the slowest growing during the initial weeks of the 42-d period and the most $\mathrm{P}$ responsive of the three species. In contrast, perennial ryegrass generally grew most rapidly in plant height and was less responsive to $\mathrm{P}$ fertilization on most soils. These differences in species growth rates and responsiveness to $\mathrm{P}$ fertilization were reflected in the soil test $\mathrm{P}$ critical levels that were determined based on the relationships between relative plant height and $\mathrm{P}$ extracted by each of the three soil test methods (Table 2). Soil test $P$ critical levels, estimated using plant height measurements between 21 to 42 d, suggest that Kentucky bluegrass, followed by tall fescue, requires higher levels of soil $\mathrm{P}$ availability than perennial ryegrass to achieve its growth potential. Plant height, however, may not be the best indicator of grass establishment because it may not be reflective of differences in biomass accumulation or density.

The relationship between relative clipping yield at $42 \mathrm{~d}$ and $\mathrm{P}$ extracted by the Mehlich-1, Bray-1, and Mehlich-3 soil test methods indicates that soil test $\mathrm{P}$ critical levels vary depending on the species and soil test method used (Fig. 1). The soil test P critical level estimates (Table 2), based on plant height or clipping yield, tended to be greater for Kentucky bluegrass than for tall fescue or perennial ryegrass. Although the soil test P critical levels for Kentucky bluegrass, based on clipping yield, could not be defined from this set of experimental soils, it is apparent that they would be greater than for tall fescue or perennial ryegrass (Fig. 1). This suggests that a higher level of available $\mathrm{P}$ is needed in the soil for Kentucky bluegrass establishment before a recommendation of zero $\mathrm{P}$ fertilizer can be justified. The ICP Mehlich-1, Bray-1, and Mehlich-3 soil test $\mathrm{P}$ critical levels, estimated from clipping yields of tall fescue or perennial ryegrass measured at $42 \mathrm{~d}$, were in the range of 170 to 280 $\mathrm{mg} \cdot \mathrm{kg}^{-1}$. Although these values tended to be slightly higher but not markedly different from critical levels suggested from previous studies with cool season grasses (Turner and Waddington, 1983) and tall fescue (Carrol et al., 2005), they are several times greater than the soil test P critical levels that are typically used for field corn production in the MidAtlantic region of the United States (23$25 \mathrm{mg} \cdot \mathrm{kg}^{-1}$ for Mehlich-1-colorimetric, $30 \mathrm{mg} \cdot \mathrm{kg}^{-1}$ for Bray-1-colorimetric, and 30 $50 \mathrm{mg} \cdot \mathrm{kg}^{-1}$ for Mehlich-3-colorimetric soil test methods) (Heckman et al., 2006) and the Mehlich-3 critical level of $36 \mathrm{mg} \cdot \mathrm{kg}^{-1}$ that is used by Rutgers Cooperative Research and Extension for general crops in New Jersey. Although these critical levels for corn would need to be slightly higher if chemical analysis were performed by ICP measurement (Heckman et al., 2006), they illustrate that a markedly higher soil fertility $\mathrm{P}$ level is required for establishment of cool season turf species than is required for field corn production. Field corn, like new grass seedings, often responds to $\mathrm{P}$ fertilization with more rapid growth early in the season. However, in the case of field corn, the early growth response often
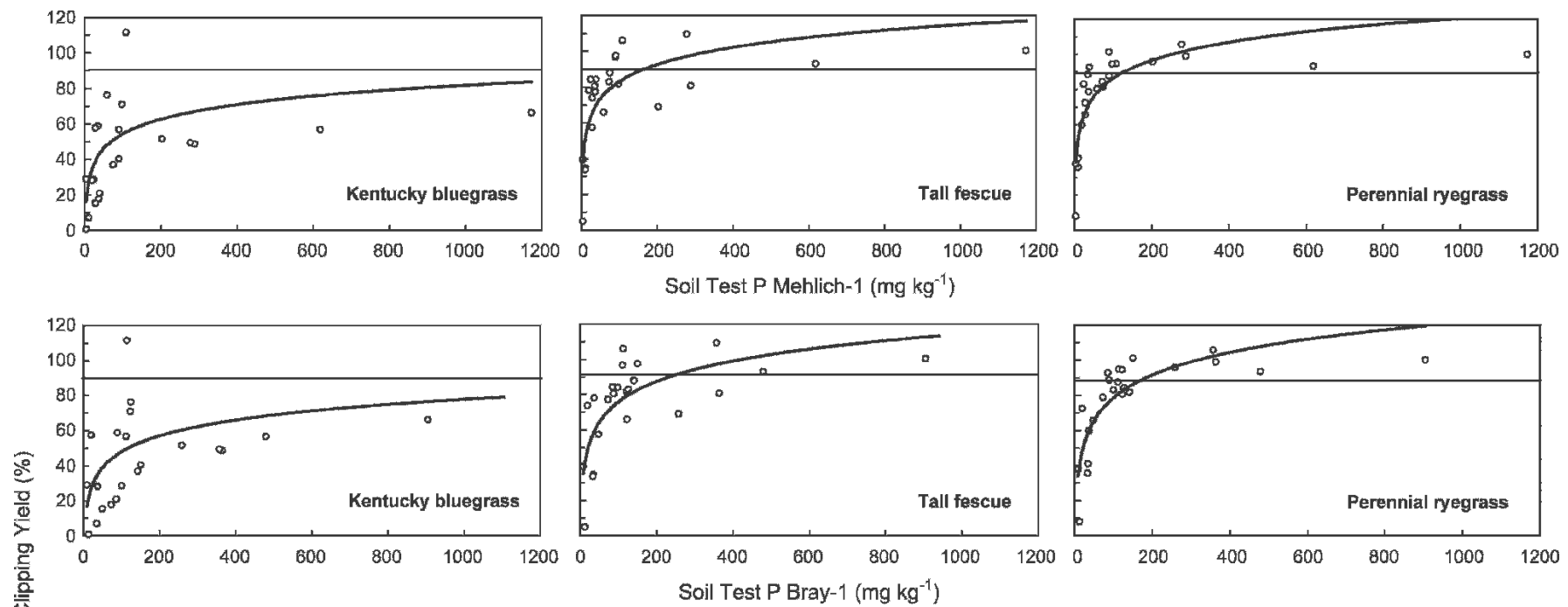

㠃
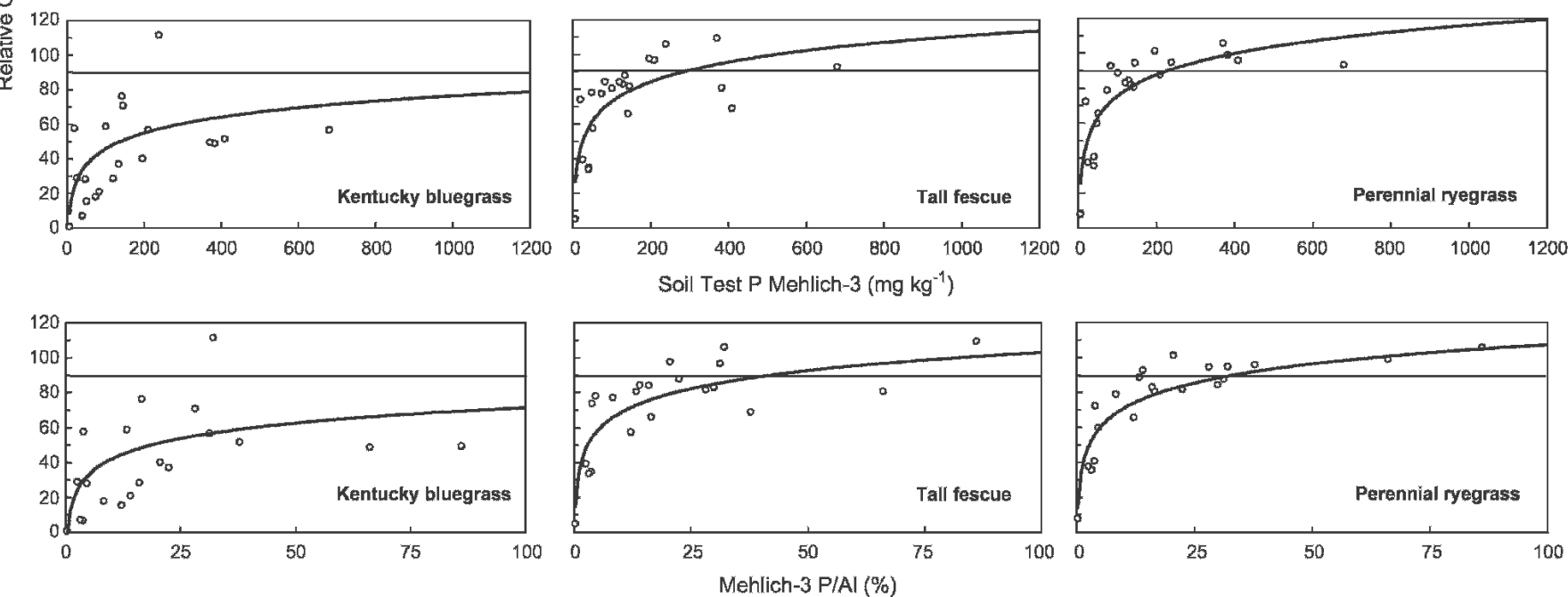

Fig. 1. Relationship between relative clipping yield of three turfgrass species at $42 \mathrm{~d}$ after seeding and soil test $\mathrm{P}$ with each of three extractants and Mehlich-3 extractable $\mathrm{P}$ to $\mathrm{AI}$ ratio, expressed as a percentage, on 23 experimental soils from New Jersey. Soil test extractable P and extractable AI were measured with an ICP instrument. 
does not translate into a grain or silage yield increase, which is the defining criteria for a specific crop soil critical level (Heckman et al., 2006). From this perspective, it becomes clear why extrapolation of soil test $\mathrm{P}$ fertility recommendations from general field crops to turfgrass is inappropriate.

The Bray-1 and Mehlich-3 soil test methods are similar with respect to chemical composition in that they both contain an acid and fluoride (Mehlich, 1984), but Mehlich-3 tends to extract more P than Bray-1 (Table 1) (Mallarino and Blackmer, 1992). Consequently, the estimated soil test $\mathrm{P}$ critical levels were greater for Mehlich-3 compared with Bray-1 when based on relative plant height and clipping yield (Table 2). The Mehlich-1 soil test method generally extracts less $\mathrm{P}$ than either the Bray-1 or Mehlich-3 soil test methods (Mehlich, 1978, 1984) and it was found as expected to exhibit lower soil test critical levels for all three grass species (Table 2).

The partitioning of the scatter of data by Cate-Nelson analysis for each species and soil test method (Table 2 and Figs. 1 and 2) suggests that any of the three soil test methods would be useful for making predictions concerning $\mathrm{P}$ fertilization for grass establishment. Soil test P critical levels, however, are not as clearly defined as may be desired to balance demands of the turf- grass industry and the environmental community. Based on the modified Cate-Nelson analysis, the number of errors, or data points in the upper left quadrant (representing incorrect predictions of unnecessary $\mathrm{P}$ fertilization) and in the lower right hand quadrant (representing an incorrect prediction to not add $\mathrm{P}$ fertilizer when it was needed), ranked from highest to lowest in number of errors as follows: Mehlich-1, Bray-1, and Mehlich-3 soil test methods (Table 2 ). In addition to having fewer upper left and lower right quadrant errors, Mehlich-3 soil test had an average correlation coefficient $\left(r^{2}=0.56\right)$ greater than for Mehlich-1 $\left(\mathrm{r}^{2}=0.51\right)$ or Bray-1 $\left(r^{2}=0.48\right)$. Most soil testing laboratories in the Mid-Atlantic region have already adopted the Mehlich-3 soil test method. Regardless of soil test method used, on average, there were more upper left type errors than lower right errors, indicating that the modified Cate-Nelson analysis used in this study estimated critical levels with a bias toward protecting against under fertilization. It may be argued that this bias serves to decrease the possibility that turfgrass managers will become dissatisfied with soil test recommendations and return to the practice of routine $\mathrm{P}$ fertilization for grass seeding regardless of soil test P level.

The ratio of $\mathrm{P}$ to $\mathrm{Al}$ extracted using Mehlich-3 extractant, which has been pro- posed as an adjunct to the Mehlich-3 soil test method to improve $\mathrm{P}$ recommendations appeared to be as good or better predictor of grass response to $\mathrm{P}$ fertilizer as the other soil test extractants that measured extractable P only (Figs. 1, 2, and 3). The Mehlich$3 \mathrm{P} / \mathrm{Al}(\%)$ critical levels, based on estimates from plant height data, varied depending on the species with perennial ryegrass exhibiting the lowest critical levels and Kentucky bluegrass the highest (Table 2). However, the Mehlich-3 P/Al (\%) critical levels, based on estimates from clipping yield data, could not be determined for Kentucky bluegrass based on the experimental soils represented in this study (Fig. 1). Apart from this exception, the ratio of $\mathrm{P}$ to $\mathrm{Al}$ extracted with Mehlich-3 extractant appears to be a better predictor (fewer upper left and lower right quadrant errors, Table 2) of a grass seeding need for $\mathrm{P}$ fertilization. This finding agrees with findings in Canada (Khiari et al., 2000) indicating that the ratio of Mehlich-3 P to Al may be a reliable method for making both agronomic and environmental $\mathrm{P}$ recommendations.

For Kentucky bluegrass, the relationships exhibited between clipping yield and soil test $P$ suggest that this grass species benefits from $P$ fertilization well above the critical levels estimated from plant height. This may be explained by the influence of $\mathrm{P}$ nutrition on
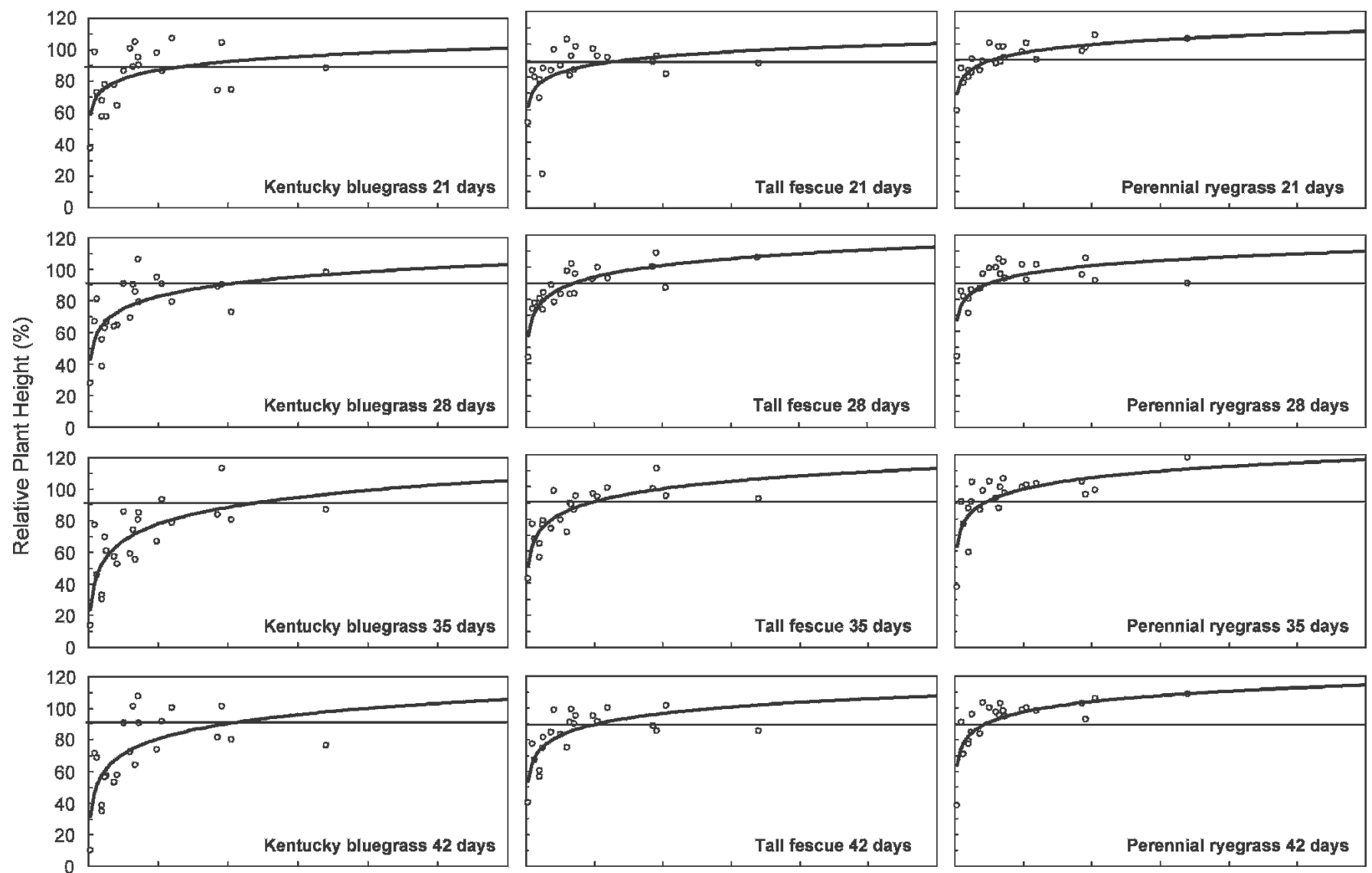

Mehlich-3 P (mg kg ${ }^{-1}$ )

Fig. 2. Relationships between relative plant height of three grass species at 21 to $42 \mathrm{~d}$ after seeding and Mehlich-3 extractable P on 23 experimental soils from New Jersey. Mehlich-3 extractable P was measured with an ICP instrument. 


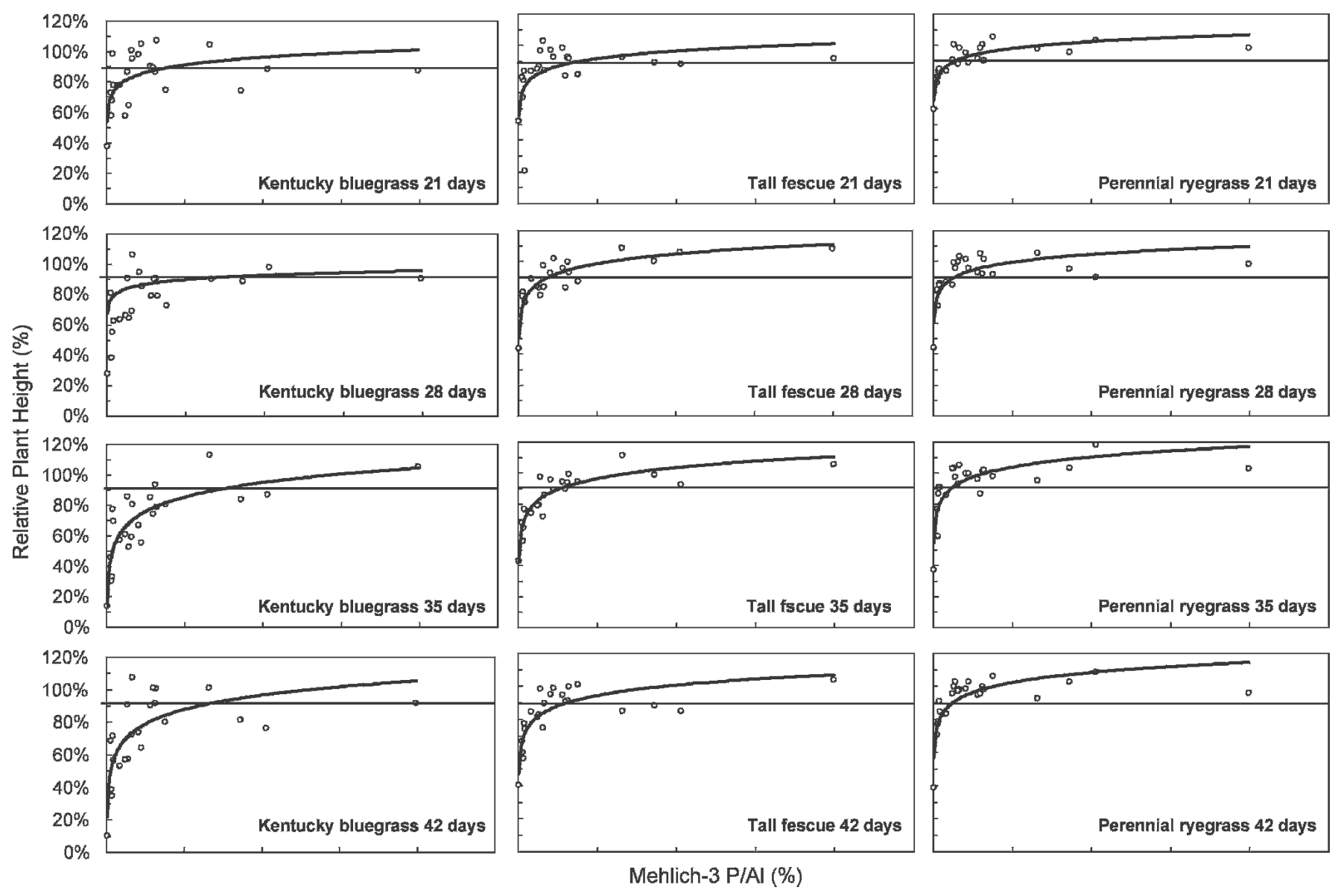

Fig. 3. Relationship between relative plant height of three grass species at 21 to $42 \mathrm{~d}$ after seeding and Mehlich-3 extractable P to AI ratio, expressed as a percentage, on 23 experimental soils. Soil test extractable $\mathrm{P}$ and extractable AI were measured with an ICP instrument.

the differing growth characteristics inherent to Kentucky bluegrass as compared with tall fescue or perennial ryegrass. Also, because Kentucky bluegrass has a smaller seed size, there are possibly lower stores of $\mathrm{P}$ in the seed to support germination, early growth, and establishment.

Although the role of soil test $\mathrm{P}$ critical levels in making fertilizer recommendations is to determine if $\mathrm{P}$ fertilizer should be recommended, plant response to $\mathrm{P}$ application rate trials provide a basis for how much $\mathrm{P}$ fertilizer should be recommended. In this context, the plant height and clipping yield responses conducted on three soils in greenhouse Expt. 2 show that grass establishment can be accelerated by relatively high rates of $\mathrm{P}$ fertilization when the soil test $\mathrm{P}$ level is well below the critical levels that were previously estimated in this study (Table 3 ). On the Woodstown soil (soil 16), which generally had the lowest soil test $\mathrm{P}$ levels in Table 1, all three grass species exhibited strong positive linear responses to $\mathrm{P}$ fertilizer rate. On the Adelphia and Freehold soils (soil 17 and soil 25, respectively, Table 1), which had soil test $\mathrm{P}$ levels just above the critical level of $36 \mathrm{mg} \cdot \mathrm{kg}^{-1}$ that is used by Rutgers Cooperative Research and Extension for general crops, the grasses exhibited less pronounced positive responses to $\mathrm{P}$ fertilizer rate. Also, on these two soils, Kentucky bluegrass was more responsive to the higher $\mathrm{P}$ application rates than was tall fescue or perennial ryegrass as indicated by the significant linear responses of Kentucky bluegrass versus the generally significant quadratic responses of perennial ryegrass and of tall fescue (Table 3 ).

The field trial conducted at Adelpha, N.J., during the fall of 1999 (Table 4) was on the same Freehold soil (soil 25, Table 1) as in greenhouse Expt. 2 (Table 3) but used visual density ratings to evaluate soil coverage or plant response to $\mathrm{P}$ instead of plant height and clipping yield. The findings from field Expt. 1 and the greenhouse Expt. 2 are in agreement with Kentucky bluegrass exhibiting positive linear responses to $\mathrm{P}$ application rate and tall fescue and perennial ryegrass exhibiting little or no response to $\mathrm{P}$ fertilization. These results from the field, along with the greenhouse data stated previously (Table 3), provide further evidence that Kentucky bluegrass is more sensitive to soil $\mathrm{P}$ availability than tall fescue or perennial ryegrass.

Field Expt. 2 conducted at Pittstown, N.J., during the spring of 2000 (Table 4) was on a Quakertown soil (soil 22, Table 1) that had a relatively high level of soil test $\mathrm{P}$ but below the estimated soil test critical levels identified in greenhouse Expt. 1. On this soil, with the exception of tall fescue on a few dates of observation, the three grass species were generally unresponsive to $\mathrm{P}$ fertilization by visual density ratings. This site represents an example of where the use of the critical levels identified in the greenhouse may have incorrectly predicted a need for P fertilization in the field.

Soil testing for $\mathrm{P}$ or the ratio of $\mathrm{P}$ to $\mathrm{Al}$ extracted with Mehlich-3 has the potential to help protect water quality by providing a means to identify sites where $P$ fertilization can accelerate grass establishment and thereby prevent soil erosion. Another potential benefit is the identification of sites that do not need $\mathrm{P}$ fertilization, thereby preventing further $\mathrm{P}$ enrichment of soil and runoff. The findings from this study show that any of the soil test extractants, Mehlich-1, Bray-1, Mehlich-3, or the ratio of $\mathrm{P}$ to $\mathrm{Al}$ extracted with Mehlich-3, when analyzed by ICP, can aid in making sound $\mathrm{P}$ recommendations for new grass seeding. Reactive $\mathrm{Al}$ is an important factor controlling P solubility in soil and when examined as the ratio of $\mathrm{P}$ to $\mathrm{Al}$ extracted with Mehlich-3 is as good or better predictor of tall fescue and perennial ryegrass establishment response to $\mathrm{P}$ fertilization than soil test $\mathrm{P}$ alone. This study found that Kentucky bluegrass establishment is more sensitive to low soil $\mathrm{P}$ availability than tall fescue or perennial ryegrass. Additional soil test calibration data, 


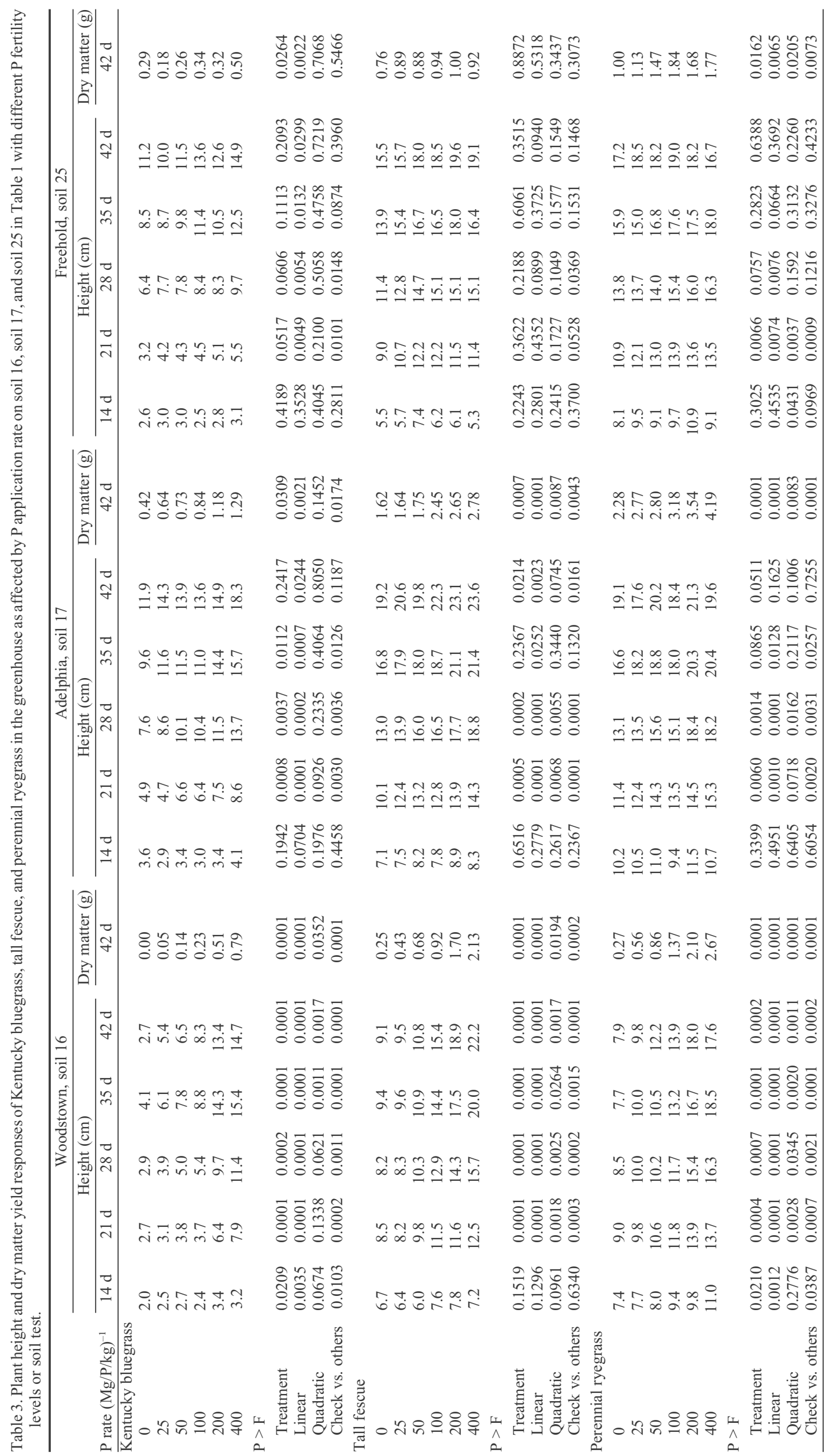


Table 4. Plant density responses (scale $0-9$ with $9=$ best) of Kentucky bluegrass, tall fescue, and perennial ryegrass evaluated in the field, as affected by $\mathrm{P}$ application rate on soil 25 and soil 22 (Table 1) with different $\mathrm{P}$ fertility levels or soil test $\mathrm{P}$.

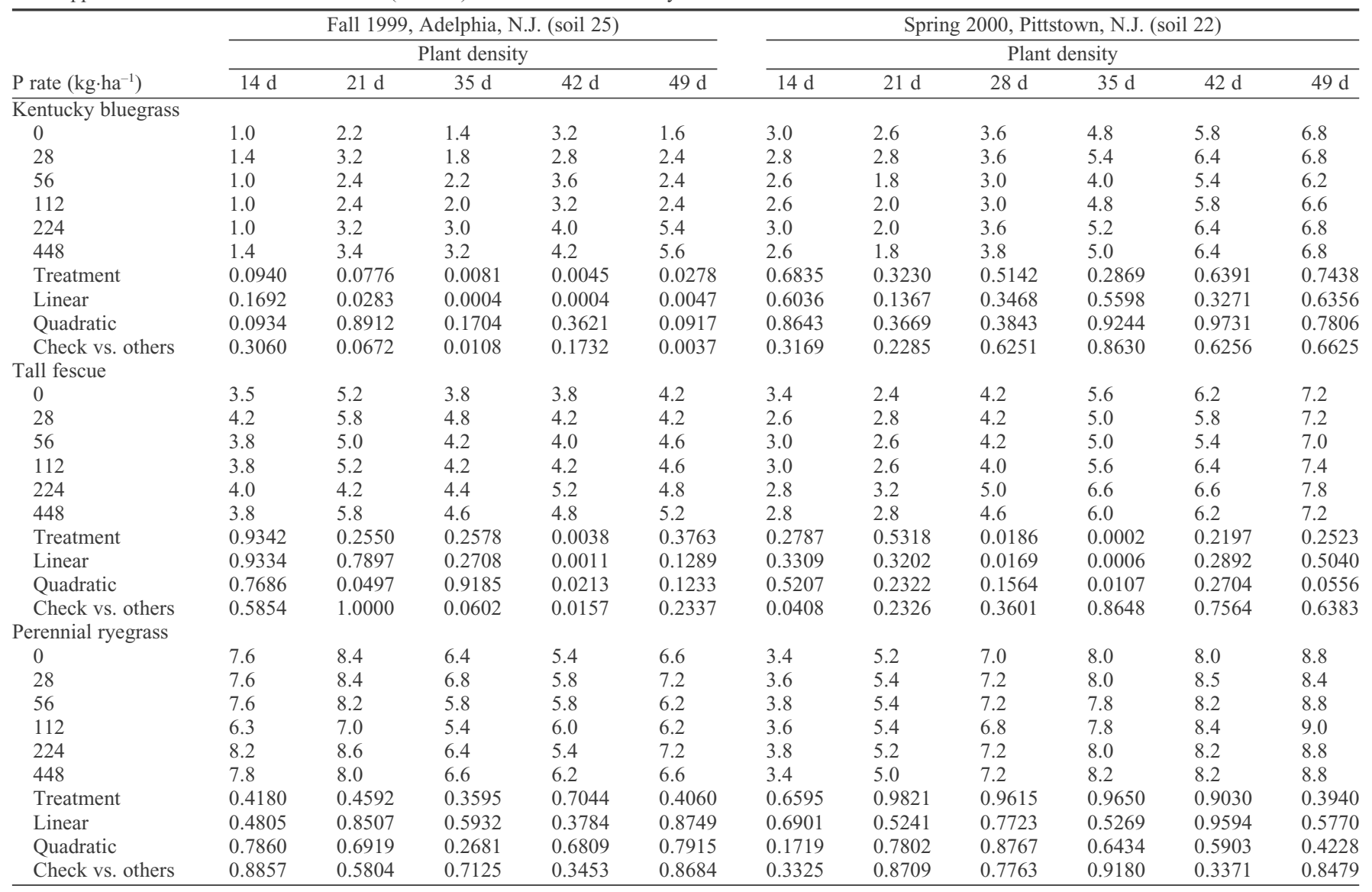

especially for Kentucky bluegrass on high $\mathrm{P}$ fertility soils, are needed to more clearly define the soil test $\mathrm{P}$ critical levels.

\section{Literature Cited}

Barber, S.A. 1980. Soil-plant interaction in plant nutrition. p. 591-615. In: F.E. Khasaumeh, E.C. Sample, and E.J. Kamprath, (eds). The role of phosphorus in agriculture. Amer. Soc. of Agron., Madison, Wisc.

Barber, S.A. 1995. Soil Nutrient Bioavailability: A Mechanistic Approach. 2nd ed. John Wiley \& Sons, New York.

Bray, R.H. and L.T. Kutz. 1945. Determination of total, organic and available forms of phosphorus in soils. Soil Sci. 59:39-45.

Carrol, M.J., T.Q. Ngo, and J.M. Krouse. 2005. Tall fescue seedling growth in response to phosphorus fertilization. Intl. Turfgrass Soc. Res. J. 10:310-317.

Cate, R.B., Jr. and L.A. Nelson. 1965. A rapid method for correlation of soil test analyses with plant response data. Tech. Bull. 1 Int. Soil Testing Ser. N.C. State Univ., Raleigh, N.C.

Correll, D. 1998. The role of phosphorus in the eutrophication of receiving waters: a review. J. Environ. Qual. 27:261-266.

Heckman, J.R., W. Jokela, T. Morris, D. Beegle, T. Sims, F. Coale, S. Herbert, T. Griffin, B. Hoskins, J. Jemison, M. Sullivan, D.K. Bhmumla, G. Estes, and W.S. Reid. 2006. Calibration of soil test phosphorus for corn in the Northeast USA. Agron. J. 98:280-288.

Hull, R.J. 1997. Phosphorus usage by turfgrasses: the energy nutrient often neglected by turf managers. TurfGrass Trends 6:2-12.
Iyamuremye, F. and R.P. Dick. 1996. Organic amendments and phosphorus sorption by soils. Adv. in Agron. 56:142.

Jokela, W.E., F.R. Magdoff, and R.P. Durieux. 1998. Improved phosphorus recommendations using Modified Morgan phosphorus and aluminum soil tests. Commun. Soil Sci. Plant Anal. 29:1739-1749.

Khiari, L., L.E. Parent, A. Pellerin, A.R.A. Alimi, C. Tremblay, R.R. Simard, and J. Fortin. 2000 An Agri-environmental phosphorus saturation index for acid coarse-textured soils. J. Environ. Qual. 29:1561-1567.

Kochian, L.V. and D.L. Jones. 1997. Aluminum and resistance in plants. In: Yokel P.A. and M.S. Golub (eds.). Research Issues in Aluminum Toxicity. Taylor and Francis Publishers, Washington, DC.

Lee, Y.S. and R.J. Bartlett. 1977. Assessing phosphorus fertilizer need based on intensity-capacity relationships. Soil Sci. Soc. Amer. J. 41:710-712.

Liu, H., J.R. Heckman, and J.A. Murphy. 1995. Screening Kentucky bluegrass for aluminum tolerance. J. Plant Nutr. 18:1797-1814.

Magdoff, F.R., C. Hryshko, W.E. Jokela, R.P. Durieux, and Y. Bu. 1999. Comparison of phosphorus soil test extractants for plant availability and environmental assessment. Soil Sci. Soc. Amer. J. 63:999-1006.

Mallarino, A.P. 2003. Field calibration for corn of the Mehlich-3 soil phosphorus test with colorimetric and inductively coupled plasma emission spectroscopy determination methods. Soil Sci. Soc. Amer. J. 68:1928-1934.

Mallarino, A.P. and A.M. Blackmer. 1992. Comparison of methods for determining critical concentrations of soil test phosphorus for corn. Agron. J. 84:850-856.
Mehlich, A. 1978. New extractant for soil test evaluation of phosphorus, potassium, magnesium, calcium, sodium, manganese, and zinc. Commun. Soil Sci. Plant Anal. 9:477492.

Mehlich, A. 1984. Mehlich 3 soil test extractant: a modification of Mehlich 2 extractant. Commun. Soil Sci. Plant Anal. 15:1409-1416.

Rosen, C.J. and B.P. Horgan. 2005. Regulation of Phosphorus fertilizer application to turf in Minnesota: Historical perspective and opportunities for research and education. Intl. Turfgrass Soc. Res. J. 10:130-135.

SAS Institute. 1997. SAS User's Guide: Statistics Version 8.0. SAS Institute, Cary, N.C.

Sharpley, A.N., S.C. Chapra, R. Wedepohl, J.T. Sims, T.C. Daniel, and K.R. Reddy. 1994. Managing agricultural phosphorus for protection of surface waters: issues and options. J. Environ. Qual. 23:437-451.

Sims, J.T. 1998. Phosphorus soil testing: Innovations for water quality protection. Commun. Soil Sci. Plant Anal. 29:1471-1489.

Sims, J.T. and A. Wolf. 1995. Recommended soil testing procedures for the Northeastern United States. 1995. Northeast Regional Publication, Bull. \#493. Agr. Exp. Sta. Univ. of Delaware, Newark, Del. http://ag.udel.edu/extension/ agnr/soiltesting.htm.

Storer, D.A. 1984. A simple high sample volume ashing procedure for determining soil organic matter. Commun. Soil Sci. Plant Anal. 15:759-772.

The Citizen of Morris County. 1992. Borough of Mountain Lakes. Ordinance, 5-92.

Turner, T.R. and D.V. Waddington. 1983. Soil test calibration for establishment of turfgrass monostands. Soil Sci. Soc. Amer. J. 47:11611166. 